of solidification, and of the relative solidification temperatures of the constituents in blends of coal.

M. Th. Mackowsky illustrated the value of microscopic investigations in studies of coke structure and strength. Proof was adduced that the macropore system of cokes, which can be studied by this method, consists of intercommunicating chambers. B. Alpern also contributed to this subject, describing the use of microscopy in reflected polarized light in recognizing coke constituents of differing optical anisotropy. It was shown that different coals in blends do not mix intimately during carbonization. S. Durif compared cokes by X-ray diffraction measurement of the degree of graphitization after heating to $2,000^{\circ}$ C. ; many factors involved in its formation at lower temperatures were shown to affect this characteristic.

Finally, A. Dahme described a method of determ. ining reactivity of coke to carbon dioxide in terms of the reaction velocity at $1,100^{\circ} \mathrm{C}$. and the activation energy of the reaction. He showed that cokes differ in the relative extent to which reaction takes place on the outer surface of the particles and on the internal surface.

\section{CONGRESS OF CELL BIOLOGY}

$\mathrm{T}$ HE Eighth International Congress for Cell Biology was held at Leyden in September 1954. It was organized by a Dutch Committee including Prof. J. Boeke as honorary president, Prof. P. J. Gaillard as president, Dr. W. K. H. Karstens and Dr. Johanna J. P. Zaaijer as secretaries. The Dutch Committee was acting on behalf of, and with the advice of, the International Society for Cell Biology.

As was the case with all the recent congresses in this field, the view was taken that cells constitute on $\Theta$ of the definitive levels of organization of living matter and that, for the proper appreciation and discussion of cellular phenomena, all cellular and sub-cellular biological phenomena are relevant. Consequently the Congress covered a very wide field. The arrangements made by the organizers provided admirably for those who wished to obtain a general view of the field, as well as for those whose interests were more restricted. In the afternoons there were a number of parallel sessions, many of them symposia, which provided for detailed discussion in a wide variety of fields. It was, of course, impracticable to attend more than one of these sessions; but the common morning sessions were organized to enable all who wished to do so to obtain a bird's-eye view of many major fields. The morning lectures were upon the following topics : induced enzyme synthesis ; intercellular substances; immunobiological concepts of growth and differentiation; biochemistry of gene action; virus synthesis ; isolated mitochondria; phase-contrast microscopy ; $\mathrm{X}$-ray methods in histochemistry; microradiography; chromosome structure; thyroid secretion; morphogenetic interaction between cells; cell division and mitotic poisons; facilitated diffusion and active transport; electron microscopy of cells. On the whole this scheme worked well ; but its success was limited by the failure of some of the lecturers to give broad surveys.

Scientifically, the chief value of the Congress lay partly in the general survey which was made of a large part of cell biology, and partly in the provision of ample time for informal discussion. One of the most valuable arrangements was the provision of discussion rooms to which any small group which arose spontaneously could resort to pursue any topic which it wished to consider. As regards subject. matter, perhaps the most striking feature was an indication that the gulf between the students of chromosome morphology and other cell biologists is beginning to narrow.

The able organization of the scientific aspects of the Congress was paralleled by the excellence of the social activities. The Congress was opened in the Pieterskirk by addresses from Prof. Gaillard, from the President of the Board of Curators and the Rector Magnificus of the University. One of the Dutch hosts remarked that the growth of fingers in tissue culture presented those interested in eriminal law with some unusual problems. The president of the Society for Cell Biology, Prof. E. N. Harvey, was prevented from attending by illness; but his speech was read by Paul Weiss in a style which was widely appreciated. There were a number of other attractive social functions, of which the most outstanding was the reception given by the Netherlands Government in the Amsterdam Rijksmuseum. Here, in addition to the permanent collection, there was a remarkable exhibition of Indonesian art. From every point of view, the Dutch Committee succeeded in making the Congress an outstanding success.

The Congress was preceded by a meeting of the Cytochemistry Commission of the Society for Cell Biology. The Commission was established in 1950, by the Society, to accelerate the study of cytochemical techniques. The Commission held a meeting, lasting two days, in Prof. Gaillard's laboratory. Recent progress in cytochemical techniques for the study of nucleic acids, proteins, polysaccharides and. various enzymes was reviewed. The Commission was able to report that much progress had been made since its first meeting (in 1951).

At the end of the Congress it was decided to accept an invitation to hold the Ninth Congress at the University of St. Andrews, Scotland. This will take place during August 28-September 3, 1957. The Executive Committee responsible for the Congress will include Dr. Honor B. Fell (chairman), Prof. H. G. Callan (secretary), Dr. Robert Brown and Prof. M. M. Swann. The following officers of the Society for Cell Biology were elected: President, Prof. P. J. Gaillard; Past-President, Prof. E. N. Harvey; Vice-Presidents, T. Caspersson, H. B. Fell, P. Weiss; Secretary, Prof. J. F. Danielli.

\section{BRITISH GELATINE AND GLUE RESEARCH ASSOCIATION RESEARCH PANEL MEETING}

HE tenth meeting of the Research Panel of the British Gelatine and Glue Research Association was held on May 17, with Mr. S. G. Hudson (Richard Hodgson and Sons, Ltd.) in the chair. Two papers were presented, and at the close of the meeting those present visited the Association's laboratories at $2 a$ Dalmeny Avenue, Holloway, London, N.7.

The first paper, "Recent Research on the Mechanism of Photographic Sensitivity", was given by Dr. J. W. Mitchell (H. H. Wills Physics Laboratory, University of Bristol). Dr. Mitchell described the recent series of experiments which he and his collaborators have carried out, aimed at providing definite experimental answers to many of the 
speculations which have been put forward from time to time to account for the behaviour of silver halide emulsions. The most important step in this work has been the preparation and use of large single crystals of silver bromide in the form of thin parallel slabs. These can be obtained either strained or, by an annealing process, strain-free.

The results of sensitization by immersion in gelatin solutions, by digestion with gelatin solutions which could be modified by the addition of reducing substances, sulphur-containing sensitizers and potassium chloro-iridite, were described. Chemical sensitization appears to arise from silver, gold or silver sulphide produced at strained or roughened regions on the surfaces of the crystals. By direct deposition of silver and gold on the surfaces, it was possible to check this view, and silver films could also be converted to silver sulphide. On exposure of silver bromide to light, halogen atoms are released, and chemical sensitizers function by reaction with the released halogen. The recent results have brought into prominence some of the older theories of sensitivity. A lively discussion, opened by $\mathbf{M r}$. R. C. M. Smith (Ilford, Ltd.), followed the paper, and gave Dr. Mitchell the opportunity to expand his account of certain aspects of the work.

The second paper, given by Dr. C. H. Bamford (Courtaulds Fundamental Research Laboratory, Maidenhead), was on "Synthetic Polypeptides", and in it the work which has been carried out at Maidenhead was reviewed and related to the behaviour of proteins. The configuration of polypeptide chains can be examined by such physical methods as absorption of polarized infra-red radiation, which enables the directions of the $-\mathrm{NH}$ and $-\mathrm{CO}$ groups to be determined, by X-ray diffraction spectra, where certain polypeptides give results in close agreement with those to be expected for the $3 \cdot 7$ helical structures proposed by Pauling, and by optical rotation. Synthetic polypeptides occur in two configurations: $\alpha$, referred to above, with intrachain hydrogen bonding; and $\beta$, an extended form with interchain hydrogen bonding. These eorrespond closely with structures found for natural proteins such as keratin and silk; but an analogue for collagen has not been found yet. The discussion on this paper was opened by Mr. A. G. Ward (British Gelatine and Glue Research Association).

A. G. WARD

\section{WATER POLLUTION RESEARCH IN BRITAIN}

$\mathrm{T}$

$O$ those whose work or interest lies in river pollution prevention, water treatment, and sewage and trado wastes purification, the study of the annual reports of the Water Pollution Research Board and of the Director of Research is at once a. necessity and a pleasure. The report for 1954* easily maintains the interest and information that have characterized previous reports.

A notable event of tho year was the completion and occupation of the new laboratories at Stevenage, Hertfordshire, which now house all the staff who were previously working at Watford, Garston, Birmingham, Coventry and Tilbury. Thus for the first time since the formation of the organization in 1927, all the

- Department of Sclentific and Industrial Research. Report of the Water Pollution Research Board, with the Report of the Director of Water Pollution Research for the year 1954. Pp. vi $+65+4$ plates. (London: H.M. Stationery Office, 1955.) $3 \mathrm{~s}$. net. staff aro together in one building-a great advantage for future work. The new laboratories have a number of novol features; among the many facilities may be instanced a small pumping station, which can deliver up to 50,000 gallons of sewage daily to experimental plant (see also Nature, June 25, p. 1105).

The largest section of the report comprises an account of the progress made in the complex survey of the Thames Estuary. Here it was found necessary to undertake the fundamental task of redetermining the values of the solubility of oxygen in water, over a range of temperatures and salinities, in equilibrium with moist air of normal composition at sea-level. The values so obtained were found to be $3-4$ per cent lower than those commonly accepted hitherto. Part of this work involved the checking of the wellknown Winkler titrimetric method for the determ. ination of dissolved oxygen against a reference gasometric method, establishing that the former is without appreciable error. Other studies included a statistical examination of the chemical records of the London County Council concerning the condition of the Thames, and the factors controlling the balance of oxygen in the estuary water-that is to say, the amount of fresh water entering at Teddington, the absorption of oxygen from the atmosphere under various surface conditions, the effect of synthetic detergents upon the absorption and the rate of oxidation of polluting matter, including the effect of bottom deposits removed by dredging. Both fieldinvestigations and laboratory experiments have now been terminated; but the final conclusions await the completion of the many lengthy calculations that have to be made.

A further section of the report deals with the effects of pollution on fish. The Laboratory has assisted the Ministry of Agriculture and Fisheries in a survey of the River Colne, principally regarding the effect of sewage effluent upon fish life. Laboratory experiments are being continued on the degree of toxicity of ammonia, carbon dioxide and synthetic detergents. It appears that the degree of toxicity is frequently related to the amount of dissolved oxygen presentfish can survive doses of toxic substances in wellaerated water that would be fatal in poorly oxygenated water.

In the section on sewage, an account is given of the examination of surface run-off water from a housing estate, the conclusion being that this water was not of a very polluting nature apart from its rather high content of suspended solids. The biological filtration of sewage is discussed as regards periodicity of dosing and efficiency of filters, and also the work so far done on the effect of synthetic detergents upon sewage treatment, where quantitative information on the subject is by no means abundant.

A useful piece of work has been done in conjunction with the Government Laboratory : that of reviewing methods for determining concentrations of various metals in waste waters and effluents down to 0.1 p.p.m. The methods suggested are due to be incorporated in the second edition of "Methods of Chemical Analysis as Applied to Sewage and Sewage Effluents" to be published by the Ministry of Housing and Local Government.

Investigations have been continued concerning the removal of cyanides from industrial waste waters by biological filtration; the organism responsible has been isolated and described. Biological destruction of cyanide in mixed plating wastes has been shown to be a practical method for dealing with such 